\title{
Antioxidant and anticoagulant activities of Ganghwa medicinal mugwort (Artemisia princeps Pampanini) extract
}

\author{
Man Jin In ${ }^{1} \cdot$ Kang Hyun Kim ${ }^{1} \cdot$ Dong Chung Kim ${ }^{1}$ \\ 강화 약쑥 (Artemisia princeps Pampanini) 추출물의 항산화 및 항웅고 활성
}

인만진 ${ }^{1}$ - 김강현 ${ }^{1}$ - 김동청 ${ }^{1}$

Received: 4 November 2020 / Accepted: 17 November 2020 / Published Online: 31 December 2020

(C) The Korean Society for Applied Biological Chemistry 2020

\begin{abstract}
In vitro antioxidant and anticoagulant activities of $50 \%$ ethanolic extract from Ganghwa medicinal mugwort (Artemisia princeps Pampanini) were investigated. The polyphenol and flavonoid contents of the mugwort extract were $106.9 \pm 3.3$ and $34.1 \pm 0.4 \mathrm{mg} / \mathrm{g}$-extract, respectively. The mugwort extract possessed a potent scavenging activity against radicals and nitrite, reducing power, and lipid peroxidation inhibition activity in a concentrationdependent manner. Also the mugwort extract delayed the plasma coagulation time through the inhibition of common coagulation pathway in a dose-dependent manner.
\end{abstract}

Keywords Anticoagulant $\cdot$ Antioxidant $\cdot$ Flavonoid $\cdot$ Medicinal mugwort (Artemisia princeps Pampanini) · Polyphenol

\section{서 론}

강화 지역에서 주로 자생하는 강화 사자발약쑥(Artemisia princeps Pampanini)은 ITS 염기서열 분석에서 참쑥(Artemisia codonocephala)보다는 황해쑥(Artemisia argyi)과 유사한 종으로

Dong Chung Kim $(\bowtie)$

E-mail:kimdc@chungwoon.ac.kr

${ }^{1}$ Department of Chemical Engineering, Chungwoon University, Incheon 22100, Republic of Korea

This is an Open Access article distributed under the terms of the Creative Commons Attribution Non-Commercial License (http://creativecommons. org/licenses/by-nc/3.0/) which permits unrestricted non-commercial use, distribution, and reproduction in any medium, provided the original work is properly cited.
분류되었다[1]. 사자발약쑥은 황해쑥과 인진쑥(Artemisia iwayomogi) 에 비해 폴리페놀과 플라보노이드 함량이 높았고[2], 항균, 항 염증, 항산화 및 항암 효과가 우수하다고 보고되었다[2-5]. 사자 발약쑥의 생리활성 물질로는 정유 성분인 cineole, camphor, borneol과 플라보노이드 화합물인 eupatilin, jaceosidin, eupafolin, epiogenin 등이 알려져 있고, 이외에도 식물성 스테롤인 sitosterol, ergosterol, stigmasterol도 함유하고 있다[6,7].

사자발약쑥 추출물은 우수한 유리라디칼 소거활성을 보여주었 고[8], Gram $(+)$ 의 피부상재균에 대해 높은 항균 활성을 보유하 고 있었으며[3], in vitro에서 사람의 간암, 폐암, 위암, 유방암 및 자궁암 세포의 증식을 효과적으로 억제하였다[5,8]. 또한 사자발 약쑥 추출물은 염증성 $\mathrm{T}$ 세포의 증식을 억제하는 항염증 효과 를 가지고 있었고[4], 사자발약쑥 추출물을 먹인 쥐에서 당화 혈 색소의 함량을 현저히 낮추는 효과가 있었다[9]. 따라서 사자발 악쑥 고유의 생리활성을 기능성 식품뿐만 아니라 항균 및 항노 화의 기능성 화장품 소재로 활용하는 연구가 시도되고 있다[2,3].

본 연구에서는 강화 사자발약쑥을 $50 \%(\mathrm{v} / \mathrm{v})$ 에탄올 용액으 로 추출한 후 폴리페놀 및 플라보노이드 함량을 측정하였고, 다 양한 항산화 활성과 혈장 항응고 활성을 확인함으로써 강화 사 자발약쑥을 다양한 생리활성 소재로 용도 확대하는데 기여하고 자 하였다.

\section{재료 및 방법}

강화 사자발약쑥 추출물의 제조, 총 폴리페놀 및 플라보노이드 함량

강화산 사자발약쑥(Isthere사, Ilsan, South Korea)의 분말에 $50 \%(\mathrm{v} / \mathrm{v})$ 에탄올 용액을 10 배 $(\mathrm{w} / \mathrm{v})$ 넣고 $50{ }^{\circ} \mathrm{C}$ 항온진탕조에 서 2 시간 동안 추출한 후 원심분리 $(3,000 \times g, 10$ 분)하여 사자발 약쑥 추출물을 얻었다. 
사자발약쑥 추출물의 폴리페놀 함량은 Folin과 Denis의 방법 으로 확인하였고, 악쑥 추출물과 Folin 용액을 혼합하여 실온에 서 5 분 반응시킨 후 $10 \% \mathrm{Na}_{2} \mathrm{CO}_{3}$ 용액을 가하여 실온에서 1 시간 정치한 다음 $725 \mathrm{~nm}$ 의 흡광도를 측정하였다[10]. 사자발 약쑥 추출물의 플라보노이드 함량은 Davis의 방법으로 확인하 였고, 약쑥 추출물에 diethylene glycol과 $1 \mathrm{~N} \mathrm{NaOH}$ 용액을 가 하고 $37^{\circ} \mathrm{C}$ 에서 1 시간 반응시킨 후 $420 \mathrm{~nm}$ 의 흡광도를 측정하 였다[11].

\section{강화 사자발약쑥 추출물의 항산화 활성}

사자발약쑥 추출물의 2,2'-azinobis-(3-ethyl-benzothiazoline)sulfonic acid (ABTS) 양이온라디칼에 대한 소거활성은 $\operatorname{Re}$ 등 의 방법으로 확인하였고, 약쑥 추출물에 $7.5 \mathrm{mM} \mathrm{ABTS} \mathrm{용액(흡}$ 광도 $=1.500 \pm 0.02$ )을 넣고 실온에서 90 분 반응시킨 후 $414 \mathrm{~nm}$ 의 흡광도를 측정하였다[12]. 사자발약쑥 추출물의 2,2-diphenyl1-picryl-hydrazyl (DPPH) 유리라디칼에 대한 소거활성은 Blois 의 방법으로 확인하였고, 약쑥 추출물에 $0.2 \mathrm{mM} \mathrm{DPPH}$ 용액을 넣고 실온에서 30 분 반응시킨 후 $517 \mathrm{~nm}$ 의 흡광도를 측정하였 다[13]. 또한, 사자발악쑥 추출물의 아질산염에 대한 소거활성은 Gray와 Dugan의 방법으로 확인하였고, $0.2 \mathrm{M}$ citrate 완충액( $\mathrm{pH}$ 1.2)에 약쑥 추출물과 $1 \mathrm{mM}$ sodium nitrite을 혼합하여 $37^{\circ} \mathrm{C}$ 에 서 1 시간 반응시키고 $2 \%$ acetic acid와 Griess 시약을 첨가하여 실온에서 15 분 정치한 후 $520 \mathrm{~nm}$ 의 흡광도를 측정하였다[14]. 양이온라디칼, 유리라디칼 및 아질산염 소거능(\%)은 [1-(실험군 의 흡광도/대조군의 흡광도) $] \times 100$ 로 계산하였다.

사자발약쑥 추출물의 환원력은 $\mathrm{Oyaizu}$ 의 방법으로 확인하였 고, $0.2 \mathrm{M}$ phosphate 완충액 $(\mathrm{pH}$ 6.68)에 약쑥 추출물과 $1 \%$ potassium ferricyanide (III)를 혼합하여 $50{ }^{\circ} \mathrm{C}$ 에서 20 분 반응시 켜 얻어진 반응액에 $10 \%$ trichloroacetic acid를 처리하여 원심 분리 $(3,000 \times g, 10$ 분)한 후, 상등액에 $0.1 \%$ ferric chloride를 넣 고 $700 \mathrm{~nm}$ 의 흡광도를 측정하였다[15]. 사자발약쑥 추출물의 지 질과산화 억제활성은 Nakatani와 Kikuzaki의 방법으로 확인하였 고, $50 \mathrm{mM}$ phosphate 완충액 $(\mathrm{pH} 7.0)$ 에서 약쑥 추출물과 2.5 $\mathrm{mg} / \mathrm{mL}$ linoleic acid를 혼합하여 $45^{\circ} \mathrm{C}$ 에서 72 시간 산화시키고 $30 \%$ ammonium thiocyanate와 혼합하여 5분 정치시킨 후 20 $\mathrm{mM}$ ferrous chloride 용액을 넣어 $500 \mathrm{~nm}$ 의 흡광도를 측정하였 다[16].

\section{강화 사자발약쑥 추출물의 혈장 항웅고 활성}

사자발약쑥 추출물의 혈장 항응고 활성은 Fox 등의 방법에 따 라 blood coagulation analyzer (CM2, Behnk Elektronik, Norderstedt, Germany)를 사용하여 activated partial thromboplastin time (aPTT), prothrombin time (PT) 및 thrombin time (TT)을 측 정하였다[17]. 이때 사람의 표준 혈장, thromboplastin, aPTT-XL 용액 및 thrombin은 Thermo Fisher Scientific사(Middletown, VA, USA)의 제품을 사용하였다. PT는 사람의 표준 혈장에 약 쑥 추출물을 넣고 $37^{\circ} \mathrm{C}$ 에서 3 분 정치시킨 후 thromboplastin 용액을 넣어 측정하였고, $\mathrm{aPTT}$ 는 사람의 표준 혈장에 약쑥 추 출물과 $\mathrm{aPTT}-\mathrm{XL}$ 용액을 넣고 $37^{\circ} \mathrm{C}$ 에서 3 분 정치시킨 후 20 $\mathrm{mM} \mathrm{CaCl} 2$ 를 넣어 측정하였다. $\mathrm{TT}$ 는 사람의 표준 혈장에 약쑥 추출물과 $20 \mathrm{mM} \mathrm{CaCl} 2$ 를 넣고 $37^{\circ} \mathrm{C}$ 에서 3 분 정치시킨 후 0.5 $\mathrm{U}$ thrombin을 넣어 측정하였다.
Table 1 Yield, polyphenol and flavonoid contents of $50 \%$ ethanolic extract of Artemisia princeps Pampanini

\begin{tabular}{ccc}
\hline \hline Yield (\%) & $\begin{array}{c}\left.\text { polyphenol content }{ }^{2}\right) \\
(\mathrm{mg} \mathrm{GAE} / \mathrm{g})\end{array}$ & $\begin{array}{c}\text { Flavonoid content }{ }^{2)} \\
(\mathrm{mg} \mathrm{QE} / \mathrm{g})\end{array}$ \\
\hline $20.6 \pm 1.2^{1)}$ & $106.9 \pm 3.3^{1)}$ & $34.1 \pm 0.4^{1)}$ \\
\hline
\end{tabular}

${ }^{1)}$ Data represented means and SD of triplicate measurements

${ }^{2}$ Polyphenol and flavonoid contents were expressed as gallic acid equivalents (GAE) and quercetin equivalents (QE), respectively

\section{결과 및 고찰}

강화 사자발약쑥의 $50 \%(\mathrm{v} / \mathrm{v})$ 에탄올 추출물의 수율은 $20.6 \pm$ $1.2 \%$ 였고, 총 폴리페놀 및 플라보노이드 함량은 추출물 $\mathrm{g}$ 당 각각 $106.9 \pm 3.3 \mathrm{mg}$ gallic acid equivalents (GAE) 및 $34.1 \pm 0.4$ $\mathrm{mg}$ quercetin equivalents $(\mathrm{QE})$ 로 나타났다(Table 1). 식물의 주 된 생리활성 물질인 폴리페놀과 플라보노이드 화합물은 우수한 항산화 활성을 갖는 것으로 알려져 있다[18]. 악쑥 추출물의 폴 리페놀 함량은 녹차잎 추출물의 $85.6 \mathrm{mg} / \mathrm{g}$ [19]과 두충잎 추출 물의 $64.1 \mathrm{mg} / \mathrm{g}$ [20] 보다 높았고, 약쑥 추출물의 플라보노이드 함량은 두충잎 추출물의 $24.0 \mathrm{mg} / \mathrm{g}$ [20]과 물엉겅퀴잎 추출물의 $13.3 \mathrm{mg} / \mathrm{g}$ [21] 보다 높게 나타나 우수한 항산화 활성을 기대할 수 있었다.

사자발약쑥 추출물은 $\mathrm{ABTS}$ 양이온라디칼과 $\mathrm{DPPH}$ 유리라디 칼을 농도 의존적으로 소거하였다(Fig. 1A). 라디칼을 $50 \%$ 소 거하는 농도인 약쑥 추출물의 $\mathrm{EC}_{50}$ 값은 $\mathrm{ABTS}$ 라디칼에 대해 서는 $226.1 \mu \mathrm{g} / \mathrm{mL}$ 이었고, DPPH 라디칼에 대해서는 $297.1 \mu \mathrm{g} /$ $\mathrm{mL}$ 이었다. 양성대조군인 L-ascorbic acid의 $\mathrm{EC}_{50}$ 값은 $\mathrm{ABTS}$ 라 디칼에 대해서는 $63.0 \mu \mathrm{g} / \mathrm{mL}$ 인 것과 $\mathrm{DPPH}$ 라디칼에 대해서는 $38.4 \mu \mathrm{g} / \mathrm{mL}$ 인 것에 비해 약쑥 추출물의 $\mathrm{EC}_{50}$ 값이 높았으나 단 일 성분이 아닌 혼합물인 것을 고려하면 약쑥 추출물의 라디칼 소거활성은 우수한 것으로 여겨진다. 이는 기존 연구에서 사자 발쑥 추출물의 $\mathrm{DPPH}$ 유리라디칼 소거에 대한 $\mathrm{EC}_{50}$ 값이 약 $200 \mu \mathrm{g} / \mathrm{mL}$ [8]로 보고된 것과 유사한 결과를 보여주었다. 또한 약용식물로 널리 알려진 두충잎 추출물의 $\mathrm{ABTS}$ 및 $\mathrm{DPPH}$ 라 디칼 소거에 대한 $\mathrm{EC}_{50}$ 값이 각각 560.6 및 $574.2 \mu \mathrm{g} / \mathrm{mL}$ 인 것 [20]에 비해 약쑥 추출물의 $\mathrm{EC}_{50}$ 값은 상당히 낮은 수준으로 나 타나 우수한 라디칼 소거활성을 보여주었다. 사자발악쑥 추출물 의 농도에 비례하여 환원력도 증가하였다(Fig. 1B). 환원력에서 흡광도가 0.5 에 되는데 필요한 농도인 $\mathrm{EC}_{50}$ 값은 약쑥 추출물에 서 $178.6 \mu \mathrm{g} / \mathrm{mL}$ 이었고, L-ascorbic acid에서는 $35.5 \mu \mathrm{g} / \mathrm{mL}$ 로 나 타났다. 두충잎 추출물과 복분자 추출물의 환원력에 대한 $\mathrm{EC}_{50}$ 값이 각각 $319.9 \mu \mathrm{g} / \mathrm{mL}$ [20]과 $871.0 \mu \mathrm{g} / \mathrm{mL}$ [22]인 것에 비해 약쑥 추출물의 $\mathrm{EC}_{50}$ 값은 상당히 낮은 수준으로 나타나 역시 환 원력도 뛰어남을 알 수 있었다.

사자발약쑥 추출물은 발암물질인 nitrosamine 생성의 근원이 되는 아질산염을 농도 의존적으로 소거하였다(Fig. 2A). 아질산 염을 $50 \%$ 소거하는 농도인 $\mathrm{EC}_{50}$ 값은 약쑥 추출물에서 976.1 $\mu \mathrm{g} / \mathrm{mL}$ 이었고, L-ascorbic acid에서는 $505.0 \mu \mathrm{g} / \mathrm{mL}$ 로 나타났다. 두충잎 추출물의 아질산염 소거에 대한 $\mathrm{EC}_{50}$ 값은 $2,329.2 \mu \mathrm{g} /$ $\mathrm{mL}$ [20]로 보고된 바 있어 약쑥 추출물의 아질산염 소거활성 은 우수하다고 여겨진다. 또한 사자발 약쑥 추출물은 지질 산 화의 산물인 과산화물의 생성을 농도 의존적으로 억제하였다 

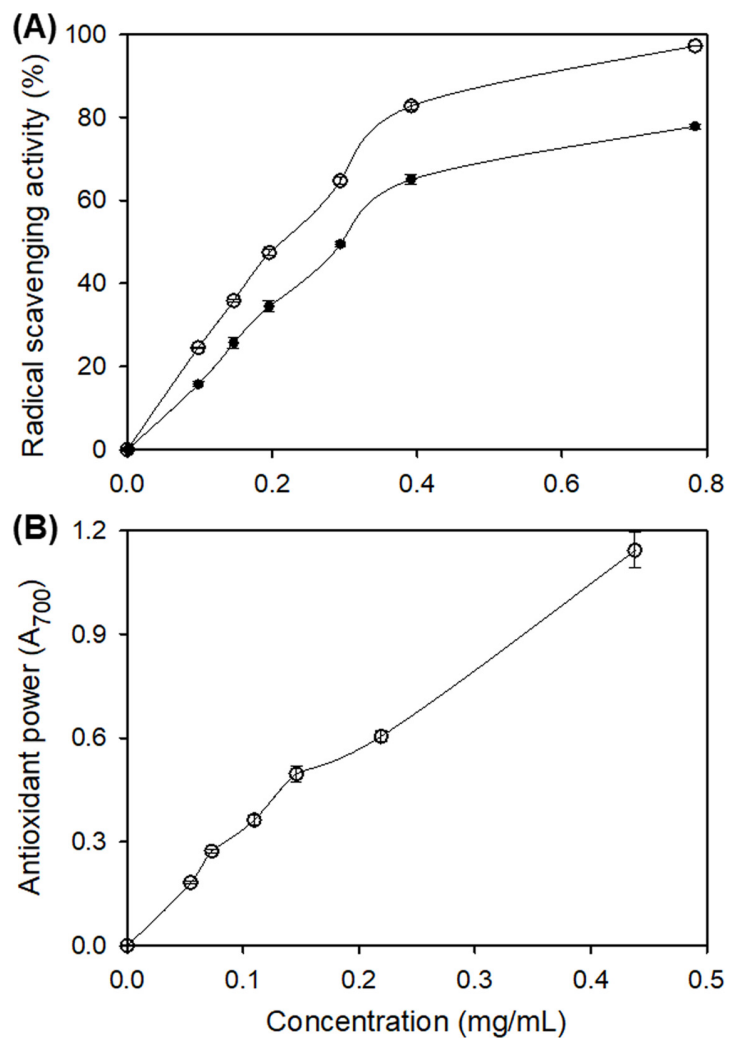

Fig. 1 (A) ABTS cation radical scavenging (- $\bigcirc-$ ) and DPPH free radical scavenging (-O) activities, and (B) Ferric reducing antioxidant power of $50 \%$ ethanolic extract from Artemisia princeps Pampanini. Data were means and SD of triplicate measurements

(Fig. 2B). 불포화 지방산이 72시간 산화되는 동안 약쑥 추출물 은 $56.5 \mu \mathrm{g} / \mathrm{mL}$ 의 농도에서 과산화물의 생성을 $67.9 \%$ 억제하였 다. 두충잎 추출물은 $74.8 \mu \mathrm{g} / \mathrm{mL}$ 의 농도에서 과산화물의 생성 을 $70.0 \%$ 억제한다는 보고[20]와 비교해서도 약쑥 추출물의 지 질과산화 억제활성은 높은 수준이었다. 강화 사자발약쑥 추출물 의 라디칼과 아질산염에 대한 우수한 소거활성, 높은 환원력 및 지질과산화 억제 활성은 그 추출물에 다량 함유되어 있는 폴리 페놀과 플라보노이드 화합물에 기인한 것으로 사료된다[23].

사자발약쑥 추출물은 농도 의존적으로 혈액응고의 공통경로 를 저해하는 혈장 항응고 활성을 보여주었다(Fig. 3). 약쑥 추 출물은 내인성 경로인 $\mathrm{aPTT}$ 와 외인성 경로인 PT에서 혈장 응 고를 지연시키는 효과가 크게 나타나지 않았으나, 공통경로인 $\mathrm{TT}$ 에서 추출물의 농도 증가에 따라 혈장응고 시간을 현저히 지 연시킴을 알 수 있었다. 악쑥 추출물은 $1.61 \mathrm{mg} / \mathrm{mL}$ 의 농도에서 TT를 $157.5 \%$ 지연시켰고, $3.22 \mathrm{mg} / \mathrm{mL}$ 의 농도에서 $182.0 \%$ 지 연시켰다. 혈액응고는 내인성 경로와 외인성 경로를 거치면서 활성화된 응고인자 Xa가 공통경로에서 연쇄 작용으로 prothrombin 을 thrombin으로 활성화시키고 이에 의해 fibrin 중합체인 혈전 이 생성되는 과정을 거친다[24]. 약쑥 추출물에 의한 TT에서의 높은 지연효과는 그 추출물이 thrombin에 의해 매개되는 fibrin 응고괴의 형성을 현저히 저해함으로써 혈장 항응고 활성을 나 타낸다고 여겨진다. 쑥 계통의 식물에 들어있는 플라보노이드
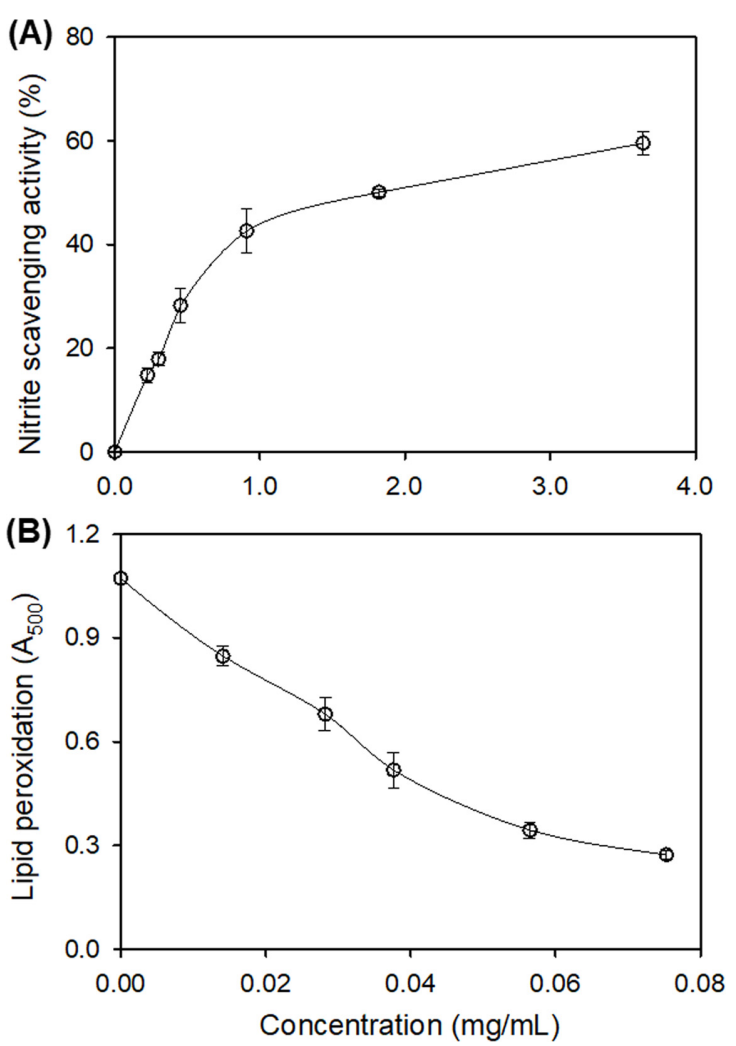

Fig. 2 (A) Nitrite scavenging activity and (B) Lipid peroxidation inhibitory activity of 50\% ethanolic extract from Artemisia princeps Pampanini. Data were means and SD of triplicate measurements

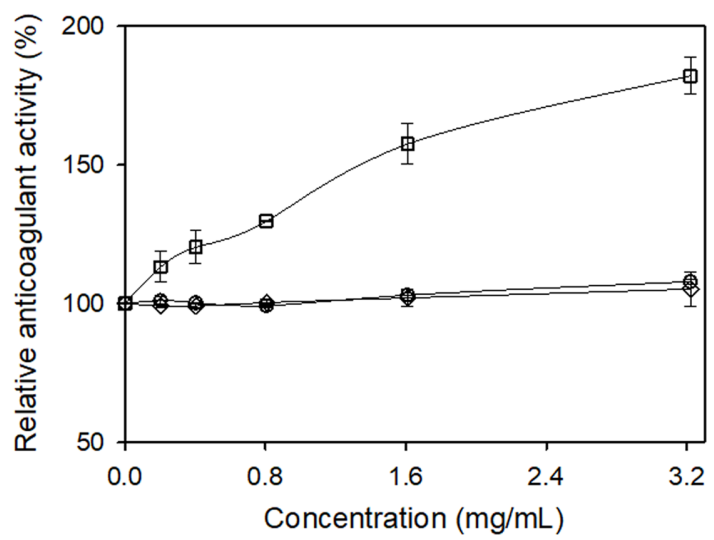

Fig. 3 Effect of 50\% ethanolic extract from Artemisia princeps Pampanini on plasma coagulation. Data presented the changes in TT (- $\square-$ ), aPTT $(-\bigcirc-)$, and PT $\left.(-\rangle_{-}\right)$as a function of the extract concentration. Data were means and SD of triplicate measurements

화합물인 eupatilin과 jaceosidin이 혈장 항응고 및 항혈소판 효 과를 나타내고[25], 폴리페놀 화합물이 혈장 항응고 활성을 가 진다는 보고[26]로 보아 악쑥 추출물의 혈장 항응고 활성은 폴 리페놀 및 플라보노이드 화합물에 기인하는 것으로 보인다.

이상의 결과로부터 강화 사자발약쑥의 $50 \%$ 에탄올 추출물은 폴리페놀과 플라보노이드 화합물을 다량 함유하고 있었고, 우수 
한 항산화 및 혈장 항응고 활성을 나타내었다. 향후 사자발약 쑥 추출물에서 생리활성 성분을 확인하고, 항산화 및 혈장 항 응고 활성의 메커니즘 규명에 대한 연구가 필요한 것으로 여겨 진다.

\section{초 록}

강화 사자발약쑥(Artemisia princeps Pampanini)으로부터 얻어진 $50 \%$ 에탄올 추출물의 항산화 및 혈장 항응고 활성을 확인하였 다. 약쑥 추출물의 폴리페놀과 플라보노이드 함량은 각각 $106.9 \pm 3.3$ 및 $34.1 \pm 0.4 \mathrm{mg} / \mathrm{g}$-추출물로 나타났다. 악쑥 추출물은 농도 의존적으로 유리라디칼, 양이온라디칼 및 아질산염을 소거 하였고, 우수한 환원력 및 지질과산화 억제효과를 나타내었다. 또한 약쑥 추출물은 농도 의존적으로 혈액응고의 공통경로를 저 해하는 혈장 항응고 활성을 나타내었다.

Keywords 사자발약쑥(Artemisia princeps Pampanini) · 폴리 페놀 · 플라보노이드 · 항산화 · 항응고

감사의 글 본 연구는 2020 학년도 청운대학교 학술연구조성비 지원에 의해 수행된 것입니다.

\section{References}

1. Park MS, Nam BM, Chung GY (2012) Taxonomic identity of Gangwha-yak-ssuk. Korean J Pl Taxon 42: 161-166

2. Choi BB, Lee HJ, Bang SK (2004) Studies on the amino acid, sugar analysis and antioxidant effect of extracts from Artemisia sp. Korean J Food Nutr 17: 86-91

3. Yang HG, Kim HJ, Kim HS, Park SN (2012) Antioxidative and antibacterial activities of Artemisia princeps Pampanini extracts. Korean J Microbiol Biotechnol 40: 250-260

4. Chang SH, Jung EJ, Park YH, Lim DG, Ko NY, Choi WS, Her E, Kim SH, Choi KD, Bae JH, Kim SH, Kang CD, Han DJ, Kim SC (2009) Anti-inflammatory effects of Artemisia princeps in antigen-stimulated $\mathrm{T}$ cells and regulatory T cells. J Pharm Pharmacol 61: 1043-1050

5. Kwon M, Kim CH, Kim HS, Lee SH, Choi GP, Park UY, You SG, Lee HY (2007) Optimal extract condition for the enhancement of anticancer activities of Artemisia princeps Pampanini. Korean J Med Crop Sci 15: 233-240

6. Ryu SN, Kang SS, Kim JS, Ku BI (2004) Quantitative analysis of eupatilin and jaceosidin in Artemisia herba. Korean J Crop Sci 49: 452456

7. Bang MH, Kim DH, Yoo JS, Lee DY, Song MC, Yang HJ, Jeong TS, Lee KT, Choi MS, Chung HG, Baek NI (2005) Isolation and identification of flavonoids from the aerial parts of Sajabalssuk (Artemisia herba). J Kor Soc Appl Biol Chem 48: 418-420
8. Kim RJ, Kang MJ, Hwang CR, Jung WJ, Shin JH (2012) Antioxidant and cancer cell growth inhibition activity of five different varieties of Artemisia cultivars in Korea. J Life Sci 22: 844-851

9. Jung UJ, Baek NI, Chung HG, Bang MH, Yoo JS, Jeong TS, Lee KT, Kang YJ, Lee MK, Kim HJ, Yeo JY, Choi MS (2007) The anti-diabetic effects of ethanol extract from two variants of Artemisia princeps Pampanini in C57BL/KsJ-db/db mice. Food Chem Toxicol 45: 20222029

10. Folin O, Denis W (1912) On phosphotungstic-phosphomolybdic compounds as color reagents. J Biol Chem 12: 239-243

11. Davis WB (1947) Determination of flavanones in citrus fruits. Anal Chem 19: 476-478

12. Re R, Pellegrini N, Proteggente A, Pannala A, Yang M, Rice-Evans C (1999) Antioxidant activity applying an improved ABTS radical cation decolorization assay. Free Radical Biol Med 26: 1231-1237

13. Blois MS (1958) Antioxidant determination by the use of a stable free radical. Nature 181: 1199-1200

14. Gray JI, Dugan Jr LR (1975) Inhibition of N-nitrosamine formation in model food system. J Food Sci 40: 981-985

15. Oyaizu M (1985) Studies on products of browning reaction: antioxidant activities of products of browning reaction prepared from glucosamine. Jap J Nutr 44: 307-315

16. Nakatani N, Kikuzaki H (1987) A new antioxidative glucoside isolated from oregano (Origanum vulgare L.). Agric Biol Chem 51: 2727-2732

17. Fox I, Dawson A, Loynds P, Eisner J, Findlen K, Levin E, Hanson D, Mant T, Wagner J, Maraganore J (1993) Anticoagulant activity of Hirulog, a direct thrombin inhibitor, in humans. Thromb Haemost 69: 157-163

18. Ardestani A, Yazdanparast R (2007) Antioxidant and free radical scavenging potential of Achillea santolina extracts. Food Chem 104: 2129

19. Jeong CH, Kang ST, Joo OS, Lee SC, Shin YH, Shim KH, Cho SH, Choi SG, Heo HJ (2009) Phenolic content, antioxidant effect and acetylcholinesterase inhibitory activity of Korean commercial green, puer, oolong, and black teas. Korean J Food Preserv 16: 230-237

20. Kim DC (2020) Antioxidative activities of ethanolic extracts of Duzhong (Eucommia ulmoides Oliver) leaf and bark. J Appl Biol Chem 63: 259-265

21. Lee SO, Lee HJ, Yu MH, Im HG, Lee IS (2005) Total polyphenol contents and antioxidant activities of methanol extracts from vegetables produced in Ullung Island. Korean J Food Sci Technol 37: 233-240

22. Jun HI, Kim YA, Kim YS (2014) Antioxidant activities of Rubus coreanus Miquel and Morus alba L. fruits. Korean Soc Food Sci Nutr 43: $381-388$

23. Arnous A, Makris DP, Kefalas P (2001) Effect of principal polyphenolic components in relation to antioxidant characteristics of aged red wines. J Agric Food Chem 49: 5736-5742

24. Nishino T, Nagumo T (1992) Anticoagulant and antithrombin activities of oversulfated fucans. Carbohydr Res 229: 355-362

25. Ryu R, Jung UJ, Kim HJ, Lee W, Bae JS, Park YB, Choi MS (2013) Anticoagulant and antiplatelet activities of Artemisia princeps Pampanini and its bioactive components. Prev Nutr Food Sci 18: 181-187

26. Zong S, Ji J, Li JL, Yang QH, Ye M (2017) Physicochemical properties and anticoagulant activity of polyphenols derived from Lachnum singerianum. J Food Drug Anal 25: 837-844 